\title{
The Bacillus subtilis L-arabinose (ara) operon: nucleotide sequence, genetic organization and expression
}

\author{
Isabel Sá-Nogueira, ${ }^{1}$ Teresa V. Nogueira, ${ }^{1}+$ Sónia Soares ${ }^{1} \neq$ \\ and Hermínia de Lencastre ${ }^{1,2}$ \\ Author for correspondence: Isabel Sá-Nogueira. Tel: +351 14426171. Fax: + 35114428766. \\ e-mail: sanoguei@itqb.unl.pt
}

1 Instituto de Tecnologia Química e Biológica, Universidade Nova de Lisboa. Apartado 127, 2780 Oeiras Codex, Portugal

2 The Rockefeller University, Laboratory of Microbiology, 1230 York Avenue, New York, NY 10021-6399, USA
The Bacillus subtilis L-arabinose metabolic genes araA, araB and ara $D$, encoding L-arabinose isomerase, L-ribulokinase and L-ribulose-5-phosphate 4-epimerase, respectively, have been cloned previously and the products of araB and araD were shown to be functionally homologous to their Escherichia coli counterparts by complementation experiments. Here we report that araA, araB and $a r a D$, whose inactivation leads to an Ara- phenotype, are the first three ORFs of a nine cistron transcriptional unit with a total length of $11 \mathrm{~kb}$. This operon, called ara, is located at about $256^{\circ}$ on the $B$. subtilis genetic map and contains six new genes named araL, araM, araN, araP, araQ and abfA.

Expression of the ara operon is directed by a strong $\sigma^{A}$-like promoter identified within a 150 bp DNA fragment upstream from the translation start site of araA. Analysis of the sequence of the ara operon showed that the putative products of araN, araP and araQ are homologous to bacterial components of binding-protein-dependent transport systems and abfA most probably encodes an $\alpha-L$-arabinofuranosidase. The functions of ara $L$ and ara $M$ are unknown. An in vitro-constructed insertion-deletion mutation in the region downstream from araD allowed us to demonstrate that araL, araM, araN, araP, araQ and abfA are not essential for L-arabinose utilization. Studies with strains bearing transcriptional fusions of the operon to the $E$. coli lacz gene revealed that expression from the ara promoter is induced by L-arabinose and repressed by glucose.

Keywords: Bacillus subtilis, L-arabinose (ara) operon, expression, catabolite repression

\section{INTRODUCTION}

Bacillus subtilis, an endospore-forming Gram-positive bacterium, is able to grow on L-arabinose as sole carbon source. L-Arabinose residues are found widely distributed among many heteropolysaccharides of different plant tissues, such as arabinans, arabinogalactans, xylans and arabinoxylans. Bacillus species in their

\footnotetext{
† Present address: Institut de Biologie Physico-Chimique, 13 Rue Pierre et Marie Curie, 75005 Paris, France.

¥Present address: Public Health Research Institute, 4.55 First Avenue, New York, NY 10016, USA.

Abbreviations: $\mathrm{Cm}$, chloramphenicol ; Em, erythromycin; $\mathrm{Km}$, kanamycin; Sp, spectinomycin.

The accession numbers for the nucleotide sequences reported in this paper are $\times 89408$ ( $a r a A, B$ and $D$ ) and X89810 (araL, $M, N, P, Q$ and $a b f A$ ).
}

natural reservoir, the soil, participate in the early stages of plant material decomposition and B. subtilis secretes three enzymes, an endo-arabanase and two arabinosidases, capable of releasing arabinosyl oligomers and Larabinose from plant cell walls (Kaji \& Saheki, 1975; Weinstein \& Albersheim, 1979). The pathway of Larabinose utilization in B. subtilis has been described by Lepesant \& Dedonder (1967a). After entering the cell, Larabinose is sequentially converted to L-ribulose, Lribulose 5-phosphate, and D-xylulose 5-phosphate by the action of $\mathrm{L}$-arabinose isomerase, $\mathrm{L}$-ribulokinase and L-ribulose-5-phosphate 4-epimerase, respectively. D-Xylulose 5-phosphate is further catabolized through the pentose phosphate pathway. Mutants unable to use Larabinose as sole carbon source, deficient in one of the three enzymes involved in L-arabinose catabolism, have been characterized, as well as constitutive mutants for 
all three enzymes (Lepesant \& Dedonder, 1967a, b). The synthesis of these enzymes was shown to be inducible by $\mathrm{L}$-arabinose and the isomerase activity is subjected to catabolite repression by glucose and glycerol (Lepesant \& Dedonder, 1967a).

A collection of $\mathrm{Ara}^{-}$B. subtilis mutants was isolated, biochemically characterized and the three metabolic genes, ara $A$, $a r a B$ and $a r a D$, encoding $L$-arabinose isomerase, L-ribulokinase and L-ribulose-5-phosphate 4epimerase, respectively, were identified and mapped between aro $G$ and leuA, at about $256^{\circ}$ on the $B$. subtilis genetic map (Paveia \& Archer, 1992a, b). Two additional classes of mutations affecting $\mathrm{L}$-arabinose utilization were identified; one included mutations conferring an $\mathrm{Ara}^{-}$phenotype to strains bearing the ara $A, a r a B$ and $a r a D$ wild-type alleles (Paveia \& Archer, $1992 \mathrm{a}, \mathrm{b})$, and another comprised mutants showing constitutive expression of the three genes (Sá-Nogueira et al., 1988). These mutations were mapped between the cys $B$ and bis $A$ markers, at about $294^{\circ}$ on the B. subtilis genetic map, and define another ara locus named araC. Expression of L-arabinose isomerase is severely repressed during growth in media containing L-arabinose plus glucose. Since L-arabinose isomerase expression is still regulated by catabolite repression in strains which contain constitutive mutations $\left(\operatorname{araC} C^{\mathrm{c}}\right), \mathrm{L}-$ arabinose transport does not play a major role in catabolite repression of expression of the metabolic enzymes (Sá-Nogueira et al., 1988). The products of the previously cloned genes araA, araB and araD were shown in complementation experiments to be functionally homologous to their Escherichia coli counterparts. Transformation experiments involving defined restriction fragments from the cloned genes showed that they are adjacent and probably constitute an operon with the order araABD (Sá-Nogueira \& Lencastre, 1989), unlike the araBAD order found in the E. coli operon (Englesberg et al., 1969).

In this communication we report the cloning of an additional $7 \cdot 1 \mathrm{~kb}$ chromosomal fragment, located downstream from araD and the nucleotide sequence of over $11 \mathrm{~kb}$. This region contains a cluster of nine genes: the metabolic genes $a r a A, a r a B$ and $a r a D$, and six new genes named araL, araM, araN, araP, araQ and $a b f A$. We have demonstrated that all genes comprise a single transcriptional unit, called the ara operon, whose expression is directed by a single $\sigma^{\mathrm{A}}$-type promoter identified within a $150 \mathrm{bp}$ DNA fragment upstream from the translation start site of araA. The $\operatorname{araN}$, araP and araQ gene products are likely components of a binding-protein-dependent transport system and $a b f A$ most probably encodes an $\alpha$-L-arabinofuranosidase. In this study we define the promoter region of the ara operon and examine its expression and regulation using transcriptional fusions of this operon to the E. coli lacZ gene. These results indicate that the ara operon is regulated at the transcriptional level because expression from the ara promoter is induced by L-arabinose and repressed by glucose.

\section{METHODS}

Bacterial strains and growth conditions. The $B$. subtilis strains used in this study are listed on Table 1. E. coli DH5 (Gibco/BRL) was used as a host for all plasmids and E. coli $\mathrm{DH} 5 \alpha \mathrm{F}^{\prime}$ (BRL) for the propagation and amplification of recombinant M13 bacteriophages. E. coli strains were grown on LB (Luria-Bertani medium; Miller, 1972). Ampicillin (Ap, $\left.75 \mu \mathrm{g} \mathrm{ml}^{-1}\right)$, chloramphenicol $\left(\mathrm{Cm}, 15 \mu \mathrm{g} \mathrm{ml}^{-1}\right)$, X-gal $\left(40 \mu \mathrm{g} \mathrm{ml}^{-1}\right)$ or IPTG $(1 \mathrm{mM})$ were added as appropriate. $B$. subtilis strains were grown on LB, SP medium (Martin et al., 1987) or minimal C medium (Pascal et al., 1971). Cm $\left(5 \mu \mathrm{g} \mathrm{ml}^{-1}\right)$, erythromycin $\left(\mathrm{Em}, 1 \mu \mathrm{g} \mathrm{m}^{-1}\right)$, kanamycin $(\mathrm{Km}$, $\left.25 \mu \mathrm{g} \mathrm{ml}^{-1}\right)$ or spectinomycin $\left(\mathrm{Sp}, 50 \mu \mathrm{g} \mathrm{ml}^{-1}\right)$ were added as appropriate. Solid medium was made with LB, SP or minimal $\mathrm{C}$ medium containing $1.5 \%(\mathrm{w} / \mathrm{v}$ ) Bacto Agar (Difco). To test for growth of $B$. subtilis integrant strains on L-arabinose as sole carbon source, strains were plated on minimal $C$ medium containing $0 \cdot 1 \%(\mathrm{w} / \mathrm{v})$ L-arabinose. The $\mathrm{AraB}^{-}$phenotype was determined on minimal $\mathrm{C}$ medium plates supplemented with $1 \%(\mathrm{w} / \mathrm{v})$ casein hydrolysate, $0.1 \% \mathrm{~L}$-arabinose and $1 \%$ $(\mathrm{w} / \mathrm{v})$ ribitol. To determine specific growth rates, the $B$. subtilis strains were grown in liquid $C$ medium with $0.4 \% \mathrm{~L}$ arabinose as sole carbon source. The cultures were incubated with aeration by shaking (130 r.p.m.) and cell growth was monitored by $\mathrm{OD}_{600}$. For $\beta$-galactosidase assays and RNA preparation the $B$. subtilis strains were grown in liquid $C$ medium supplemented with $1 \%(\mathrm{w} / \mathrm{v})$ casein hydrolysate, and $\mathrm{L}$-arabinose and glucose were added to the cultures when necessary at a final concentration of $0 \cdot 4 \%(\mathrm{w} / \mathrm{v})$.

DNA manipulations and sequencing. DNA manipulations were carried out according to Sambrook et al. (1989). Enzymes were purchased from commercial suppliers and used according to the manufacturers' instructions. DNA sequencing was performed by the method of Sanger et al. (1977) with the Sequenase Kit (T7 DNA polymerase; USB). Sequencing templates were prepared by a combination of subcloning appropriate fragments from pSNL1 and pSNL9 into the polycloning site of M13mp19 or M13mp18 (Yanisch-Perron et al., 1985) and sequential deletion of the recombinant M13 derivatives, by the method of Dale et al. (1985), using the Cyclone Biosystem Kit (International Biotechnologies Inc.). The DNA sequence was determined on both strands and across all the restriction sites used for subcloning. The primer 5' CCTCTTCGCTATTACGCC 3', complementary to the coding sequence of $l a c Z$, was used to sequence the transcriptional lac Z fusions.

Plasmid constructions. pSNL7 was constructed by subcloning a 959 bp SmaI-PstI DNA fragment (nt 938-1897, Fig. 1) from pSNL1 (Sá-Nogueira \& Lencastre, 1989) between the SmaI and PstI sites of the integrational vector pJM783 (Perego, 1983). To construct pSS2, we digested pSNL1 (Sá-Nogueira \& Lencastre, 1989) with HindIII and XhoI and cloned a purified fragment of 965 bp (nt 3815-4780, Fig. 1) between the HindIII and SalI sites of the integrating vector pJH101 (Ferrari et al., 1983). pTN10 was obtained by subcloning a 789 bp HindIIIHincII DNA fragment (nt 6545-7334, Fig. 1) from pSS3 between the HindIII and EcoRV sites of the integrational vector pJH101 (Ferrari et al., 1983). pTN14 was constructed by subcloning the $678 \mathrm{bp} S m a I-B g l$ II DNA fragment (nt 8242-8920, Fig. 1) from pTN13 between the BamHI and SstI (fill-in) sites of pJM783 (Perego, 1993). pSNL10 was obtained by subcloning a $1.7 \mathrm{~kb}$ EcoRI-HincII fragment (nt 2681-4416, Fig. 1) from pSNL1 (Sá-Nogueira \& Lencastre, 1989) between the EcoRI and SmaI sites of pMK4 (Sullivan et al., 1984). 
Table 1. B. subtilis strains

\begin{tabular}{|c|c|c|c|}
\hline Strain* & Genotype & Phenotype & Source $†$ \\
\hline $168 \mathrm{~T}^{+}$ & Prototroph & $\mathrm{Ara}^{+}$ & F. E. Young \\
\hline BR151 & metB10 lys 3 trpC2 & $\mathrm{Ara}^{+}$ & F. E. Young \\
\hline IQB100 & $a r a B^{\prime}:: \mathrm{pSNL} 7(a r a B-c a t$ lacZ) & $\mathrm{Cm}^{\mathbf{r}} \mathrm{Ara}^{-}$ & $\mathrm{pSNL7} \rightarrow 168 \mathrm{~T}^{+}$ \\
\hline IQB101 & $a r a B^{\prime}:: l a c Z$ erm & $\mathrm{LacZ}^{+} \mathrm{Em}^{\mathrm{r}} \mathrm{Ara}^{-}$ & $\mathrm{pSNL} 11 \neq \rightarrow 168 \mathrm{~T}^{+}$ \\
\hline IQB102 & $a r a B^{\prime}:$ :erm lacZ & $\mathrm{LacZ}^{-} \mathrm{Em}^{\mathrm{r}} \mathrm{Ara}^{-}$ & pSNL12 $\ddagger \rightarrow 168 \mathrm{~T}^{+}$ \\
\hline IQB103 & $\operatorname{ara} A^{\prime}:: \mathrm{pSNL} 13(\operatorname{araA}-\operatorname{lacZ} c a t)$ & $\mathrm{LacZ}^{+} \mathrm{Cm}^{\mathrm{r}} \mathrm{Ara}^{-}$ & $\mathrm{pSNL} 13 \rightarrow 168 \mathrm{~T}^{+}$ \\
\hline IQB104 & $\operatorname{ara} A^{\prime}:: \mathrm{pSNL} 14$ (araA-cat lacZ) & $\mathrm{LacZ}^{-} \mathrm{Cm}^{\mathrm{r}} \mathrm{Ara}^{+}$ & $\mathrm{pSNL} 14 \rightarrow 168 \mathrm{~T}^{+}$ \\
\hline IQB202 & $\operatorname{araL} L^{\prime}:$ pSS2 (araL-amp cat) & $\mathrm{Cm}^{\mathrm{r}} \mathrm{Ara}^{+}$ & $\mathrm{pSS} 2 \rightarrow 168 \mathrm{~T}^{+}$ \\
\hline IQB204 & $\operatorname{araN^{\prime }}:: \mathrm{pTN} 10($ araN-cat amp) & $\mathrm{Cm}^{\mathrm{r}} \mathrm{Ara}^{+}$ & $\mathrm{pTN} 10 \rightarrow 168 \mathrm{~T}^{+}$ \\
\hline IQB205 & $\operatorname{ara} Q^{\prime}:: \mathrm{pTN} 14\left(\operatorname{araQ}-l a c Z^{\prime} c a t\right)$ & $\mathrm{LacZ}^{-} \mathrm{Cm}^{\mathrm{r}} \mathrm{Ara}^{+}$ & $\mathrm{pTN} 14 \rightarrow 168 \mathrm{~T}^{+}$ \\
\hline IQB206 & $\Delta a r a \mathrm{~L}-a b f A:: s p c$ & $\mathrm{Sp}^{\mathrm{r}} \mathrm{Ara}^{+}$ & pSN22 $\neq \rightarrow 168 \mathrm{~T}^{+}$ \\
\hline
\end{tabular}

"All strains are derivatives of $B$. subtilis $168 \mathrm{~T}^{+}$.

†The arrows indicate transformation and point from donor DNA to recipient strain. F. E. Young, University of Rochester New York, USA.

‡Transformation was carried out with linearized plasmid DNA.

pSNL11 and pSNL12 were obtained as follows. A $4.5 \mathrm{~kb}$ BamHI-HindIII (fill-in) fragment extracted from pMC11 (Debarbouillé et al., 1990), containing lacZ and erm from pTV32 (Perkins \& Youngman, 1986), was subcloned in both orientations at the unique EcoR V restriction site (nt 3214, Fig. 1) of pSNL10. pSNL13 and pSNL14 were obtained by subcloning a 470 bp DraI-EcoRV DNA fragment (nt 82-552, Fig. 1) from pSNL9 at the unique SmaI site of the integrational vector pJM783 (Perego, 1993) in both orientations. pSNL13 contains lac $Z$ in the same orientation as the araA region sequences and pSNL14 contains lacZ in the opposite orientation. pSN20 was constructed by cloning the $1.2 \mathrm{~kb}$ EcoRVHincII fragment (nt 3214-4416, Fig. 1) from pSS3 into the SmaI site of pAH248 [a pGem-7Zf $(+)$ (Promega) derivative that contains a $\mathrm{Km}^{\mathrm{r}}$ gene cloned between its $\mathrm{XboI}$ and EcoRI sites (A. O. Henriques \& C. P. Moran Jr, Emory University School of Medicine, Atlanta, GA, USA, personal communication)]. To obtain pSN21 a $1.7 \mathrm{~kb}$ EcoRV fragment from pSN5 (nt 10632-about 12332, Fig. 1) was inserted into the HincII site of pAH250 [a pBluescript SK + (Stratagene) derivative that contains a $S p^{r}$ gene $(s p c)$ cloned into the EcoRV site (A. O. Henriques, B. W. Beall \& C. P. Moran Jr, personal communication)]. To construct pSN22, we digested pSN20 with PstI and NsiI and cloned a purified fragment of about 2790 bp, which contains the $\mathrm{Km}^{\mathrm{r}}$ gene, in the SmaI site of pSN21. pSNL9, pSS3, pTN13 and pSN5 were obtained by cutting chromosomal DNA from $B$. subtilis strains IQB100, IQB202, IQB204 and IQB205 (Table 1) with HindIII, EcoRI, NcoI and SmaI, respectively, followed by circularization of the DNA fragments at low concentration.

Bacterial transformation. B. subtilis DNA transformations were performed according to the method of Anagnostopoulos \& Spizizen (1961). E. coli transformations were carried out according to standard methods (Sambrook et al., 1989).

$\boldsymbol{\beta}$-Galactosidase assays. Strains of $B$. subtilis harbouring transcriptional lacZ fusions were grown in $75 \mathrm{ml} \mathrm{C}$ medium supplemented with $1 \%$ casein hydrolysate. During early exponential phase $\left(\mathrm{OD}_{600}=0 \cdot 11-0 \cdot 15\right) 25 \mathrm{ml}$ of the culture was transferred to two different flasks and L-arabinose at a final concentration of $0.4 \%$ or both $\mathrm{L}$-arabinose and glucose each at a final concentration of $0.4 \%$ were added. At this time, $t_{0}, 100 \mu \mathrm{l}$ aliquots of cell culture were collected, harvested and stored at $-70^{\circ} \mathrm{C}$ overnight. Exponential growth of the three cultures was followed by measuring $\mathrm{OD}_{600}$ and at $30 \mathrm{~min}$ intervals, $100 \mu \mathrm{l}$ of cell culture samples was removed and stored at $-70^{\circ} \mathrm{C}$ until the cultures reached an $\mathrm{OD}_{600}=$ $0.7-0.8$, which corresponds to growth for at least 2.5 generations in the presence of the inducer. The cells were resuspended in $1 \mathrm{ml} \mathrm{Z}$ buffer (Miller, 1972) and two drops of chloroform plus one drop of $0 \cdot 1 \%$ SDS were added and mixed vigorously for $10 \mathrm{~s}$ on a table top vortex apparatus. $\beta$ Galactosidase activity was determined as described by Miller (1972) using the substrate ONPG.

RNA preparation, Northern blotting and primer extension analysis. B. subtilis 151 or $168 \mathrm{~T}^{+}$cells were grown in $\mathrm{C}$ medium supplemented with $1 \%$ casein hydrolysate in the presence and absence of $\mathrm{L}$-arabinose at a final concentration of $0.4 \%$. Cells were harvested during late exponential phase $\left(\mathrm{OD}_{600} \sim 0.9\right)$ and RNA prepared as described by Igo \& Losick (1986). For Northern blot analysis, 2·5-10 $\mu \mathrm{g}$ total RNA was run in $1 \cdot 0-1 \cdot 2 \%(\mathrm{w} / \mathrm{v})$ agarose/formaldehyde and transferred to positively charged nylon membranes (Hybond$\mathrm{N}+$, Amersham) according to standard methods (Sambrook et al., 1989). Size determination was done using an RNA ladder (0.24-9.5 kb; Gibco/BRL). The probes were labelled using the Multiprime random-prime DNA labelling system from Amersham and $\left[\alpha^{32} \mathrm{P}\right] \mathrm{dATP}\left[3000 \mathrm{Ci} \mathrm{mmol}^{-1}(111 \mathrm{TBq}\right.$ $\left.\left.\mathrm{mmol}^{-1}\right)\right]$. Primer extension analysis was performed as described by Sambrook et al. (1989). The two synthetic oligonucleotides used in primer extension experiments were primer A (5' GAAGCATGTAAACTGCCCC 3'), complementary to nt 216-234 (Fig. 1), and primer B (5' CCAGCGTCTCTTCCCCG $3^{\prime}$ ), complementary to nt 283-300 (Fig. 1). The two oligonucleotides were used in separate experiments to rule out the possibility of primer-specific artifacts. A total of $10 \mathrm{ng}$ of primer was used in the labelling reaction mixed with $25 \mu \mathrm{g}$ RNA, denatured by heating to $85^{\circ} \mathrm{C}$ for $10 \mathrm{~min}$ and annealed by incubation at $42^{\circ} \mathrm{C}$ for $3 \mathrm{~h}$. The oligonucleotide primer was extended using 15 units of avian myeloblastosis virus reverse transcriptase for $2 \mathrm{~h}$ at $37^{\circ} \mathrm{C}$, as described by 
1 AAGCTTCTCATCAATGATTTGAATTGGAGCTCGGGCTGGCCGTCCTATTGAATTAAAAAGCCGGCTCTGCCCCCCGGCTITIITTAAAAGAAAAGATTGAC

$-10+1$

101AGTATAATAGTCAATTACTATAATAAAATTGTTCGTACAAATATTTATTTATAGGTTTATTTTCTATCATTAGTACGTATCTTTGTATTGAAAGCGT

$>\operatorname{IR}<\ll<<<<$

$\gg>\gg \gg \gg>>\mid R<\ll<<<<$

$>\gg \gg \gg \gg>\mid R \ll<<<<<<$

rbs ARaA-M L Q $T$ T K D D Y

201 TTATITTATGAGAAAGGGGCAGTTTACATGCTTCAGACAAAGGATTATGAATTCTGGTTIGTGACAGGAAGCCAGCACCTATACGGGGAAGAGACGCTGG

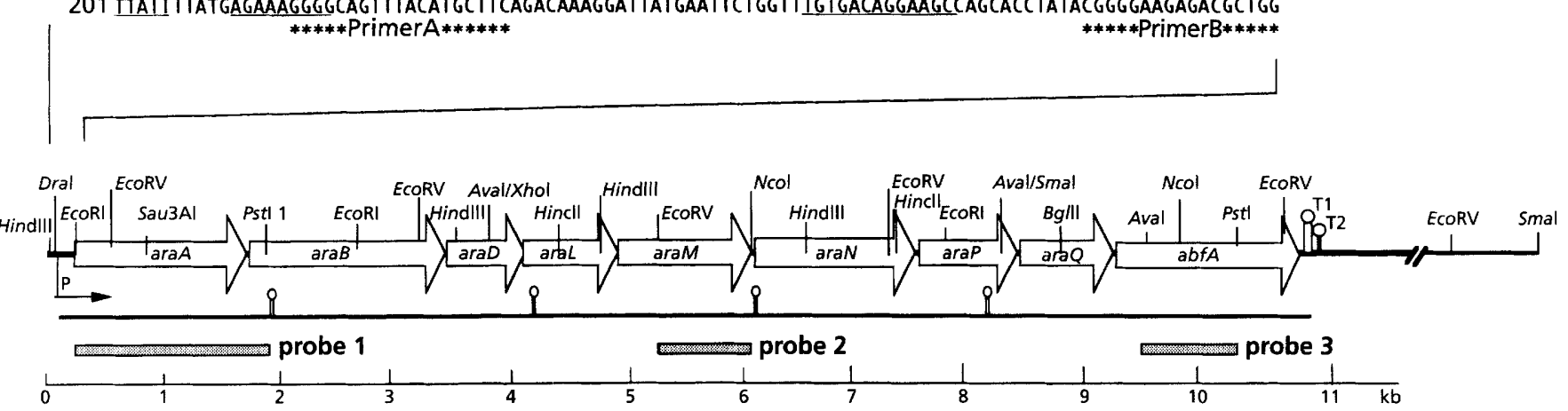

pSNL1 -

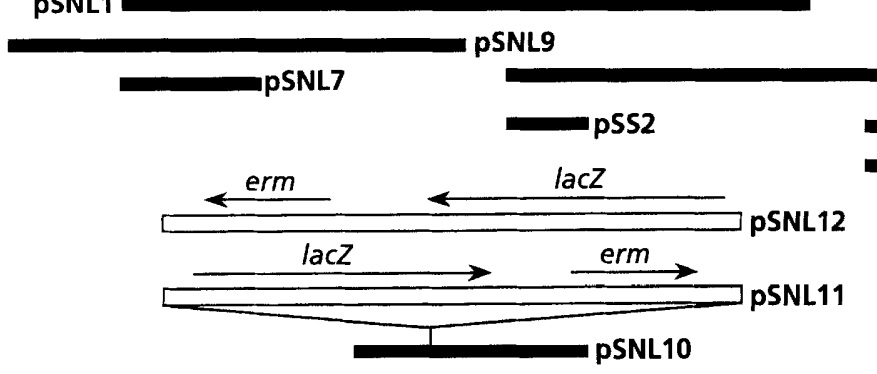

pSNL13, pSNL14

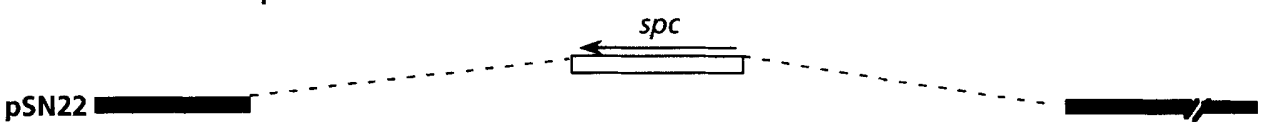

Fig. 1. Physical and genetic map of the ara region of the chromosome. The location and direction of transcription of the nine ORFs ( $a r a A, B, D, L, M, N, P, Q$ and abfA), predicted from the analysis of the nucleotide sequence, are indicated by arrows. The promoter $(P)$ of the ara operon, defined by primer extension, is located upstream from ara $A$ and the two regions of dyad symmetry ( $\mathrm{T} 1$ and $\mathrm{T} 2$ ) that could represent the terminators of the ara transcriptional unit are located downstream from abfA. Relevant restriction sites are given in the partial restriction map. The region to the right of the EcoRI site (position 11755) is not drawn to scale. Immediately below the physical map the ara operon transcript is schematically shown and putative secondary structures of the mRNA are indicated by stem-loop structures. The grey boxes, below the physical map, represent the three fragments used as probes for Northern analysis of the ara transcripts and the black boxes represent the extent of the inserts in the indicated plasmids. The sites of different insertion-deletion mutations resulting from replacement of wild-type sequences, by double cross-over events (confirmed by Southern blot analysis, data not shown), with in vitro-engineered fragments of the ara region, present in plasmids pSNL11, pSNL12 and pSN22, are also shown. Plasmids pSNL7, pSS2, pTN10, pTN14, pSNL13 and pSNL14 were integrated into the host chromosome by means of a single cross-over (Campbell-type) recombinational event that occurred in the region of homology (confirmed by Southern blot analysis, data not shown). The ara operon promoter nucleotide sequence of the non-transcribed strand is shown in the $5^{\prime}-3^{\prime}$ direction above the physical map. The predicted $\mathrm{N}$-terminal region of the polypeptide encoded by $\operatorname{ara} A$ is given in single letter code. The transcription start site $(+1)$, defined by primer extension analysis, the -35 and -10 regions of the promoter and the putative ribosome binding site (rbs) are underlined. Convergent arrows represent different regions of dyad symmetry (IR) and the complementary sequence of the two primers $A$ and $B$, used in primer extension analysis are represented below the sequence. The two putative catabolicrepression-associated sequences (positions 191-204 and 260-273) are underlined.

Sambrook et al. (1989). Analysis of the extended products was carried out on $7.5 \%$ polyacrylamide urea gels.

Computer analysis. Amino acid sequences were deduced from the nucleotide sequence using DNASIS V2.0 (Hitachi Software Engineering, 1991). The GenBank and EMBL databases were accessed using the GCG package of sequence analysis software (Genetics Computer Group, Madison, Wisconsin, USA).

\section{RESULTS}

\section{Insertional inactivation of $a r a B$ and cloning of an intact copy of araA}

The location of the araA locus at one end of the cloned fragment in pSNL1 (Fig. 1), together with the absence of araA complementation with pSNL1, suggested that only 
Table 2. Percentage amino acid identity between the predicted sequences of the Ara proteins and similar proteins

\begin{tabular}{|c|c|c|c|c|}
\hline $\begin{array}{l}\text { B. subtilis } \\
\text { AraA protein }\end{array}$ & Homologue (species/accession no.) ${ }^{*}$ & Function & Identity $(\%)$ & $\begin{array}{c}\text { Amino acid } \\
\text { overlap }\end{array}$ \\
\hline \multirow[t]{2}{*}{ AraA } & $\operatorname{AraA}(E$. coli/M15263) & $\mathrm{L}$-Arabinose isomerase & $52 \cdot 9$ & 495 \\
\hline & AraA (Sal. typhimurium/M11047) & $\mathrm{L}$-Arabinose isomerase & $52 \cdot 9$ & 495 \\
\hline \multirow[t]{2}{*}{ AraB } & $\operatorname{AraB}($ E. coli/M15263) & L-Ribulokinase & $25 \cdot 7$ & 552 \\
\hline & AraB (Sal. typhimurium/M11045) & L-Ribulokinase & $30 \cdot 6$ & 350 \\
\hline AraL & $\mathrm{NagD}($ E. coli/X14135) & Unknown & $25 \cdot 5$ & 251 \\
\hline \multirow[t]{3}{*}{$\operatorname{AraN}$} & LacE (Agrobacterium radiobacter/X66596) & Lactose-binding protein & $26 \cdot 2$ & 302 \\
\hline & MalX (Streptococcus pneumoniae/L08611) & Maltose-binding protein & $24 \cdot 1$ & 345 \\
\hline & $\begin{array}{l}\text { AmyE (Thermoanaerobacterium } \\
\text { thermosulfurigens/M57692) }\end{array}$ & Starch-binding protein & $21 \cdot 7$ & 369 \\
\hline AraP & MalC (Streptococcus pneumoniae/L08611) & Membrane protein & $25 \cdot 2$ & 298 \\
\hline \multirow[t]{4}{*}{ AraQ } & LacG (Agrobacterium radicbacter $/ \mathrm{X} 66596)$ & Membrane protein & $32 \cdot 7$ & 254 \\
\hline & UgpE (E. coli/X13141) & Membrane protein & $22 \cdot 9$ & 279 \\
\hline & $\begin{array}{l}\text { AmyC (Thermoanaerobacterium } \\
\text { thermosulfurigens/M57692) }\end{array}$ & Membrane protein & $28 \cdot 2$ & 262 \\
\hline & MalD (Streptococcus pneumoniae/L08611) & Membrane protein & $25 \cdot 6$ & 262 \\
\hline AbfA & AbfA (Streptomyces lividans/U04630) & $\alpha$-L-Arabinofuranosidase & $52 \cdot 6$ & 500 \\
\hline
\end{tabular}

part of araA was present in this plasmid (Sá-Nogueira \& Lencastre, 1989). To clone the entire araA gene, plasmid pSNL7 (Fig. 1) was integrated, as single copy, into the $B$. subtilis $168 \mathrm{~T}^{+}$chromosome at the ara $A$ and araB region of homology. This procedure causes disruption of the transcriptional unit and the structure of the resulting strain IQB100 that was unable to grow on minimal medium containing L-arabinose as sole carbon source, confirming the polar effect of the insertion on the genes located downstream from araA. Furthermore, strain IQB100 showed resistance to ribitol in the presence of $\mathrm{L}$ arabinose on minimal medium plates supplemented with $1 \%$ casein hydrolysate. In $B$. subtilis (Paveia \& Archer, 1992a), like in E. coli (Katz, 1970), these results indicate a defective $a r a B$. Chromosomal DNA from IQB100 was used to rescue the entire araA gene and its upstream region (see Methods). The structure of the recircularized plasmid, pSNL9, was analysed and it contains a $950 \mathrm{bp}$ fragment of DNA upstream from the previously cloned DNA in plasmid pSNL7 (Fig. 1).

\section{Cloning of the chromosomal region extending downstream from $a r a D$}

To clone the region located downstream from araD, an integrational plasmid, pSS2, carrying sequences of araD and araL (Fig. 1), was transformed into the wild-type strain $168 \mathrm{~T}^{+}$. After integration as single copy, the resulting strain IQB202 presented an $\mathrm{Ara}^{+}$phenotype although the growth on minimal medium plates with Larabinose as sole carbon source was slower than that observed with the wild-type strain $168 \mathrm{~T}^{+}$(see Discussion below). The digestion of total chromosomal DNA from IQB202 followed by circularization of the fragments yielded plasmid pSS3 that includes a $3.0 \mathrm{~kb}$ insert located downstream to the fragment cloned in pSS2 (Fig. 1). To obtain a fragment that would contain the downstream region from araN, we performed a second chromosome walking step, using integrational plasmid pTN10 (Fig. 1). This procedure created plasmid pTN13 that carried an additional $3 \cdot 2 \mathrm{~kb}$ of DNA adjacent to the previously cloned fragment in plasmid pTN10 (Fig. 1). Strain IQB204, which resulted from the integration of plasmid pTN10 (Fig. 1) into the chromosome of the wild-type strain $168 \mathrm{~T}^{+}$showed a $\mathrm{Ara}^{+}$phenotype similar to that seen with IQB202. A third chromosome walking step rightwards from pTN13, using integrational plasmid pTN14 (Fig. 1), isolated a $4.7 \mathrm{~kb}$ Smal fragment (plasmid pSN5). Plasmid pTN14, when integrated into the chromosome of strain IQB205 as single copy, caused an $\mathrm{Ara}^{+}$phenotype. The structure of the inserts in pSS3, pTN13 and pSN5 was compared to that of the corresponding areas of chromosomal DNA by Southern blot analysis (data not shown) and the results revealed that no detectable rearrangement occurred during the cloning process.

\section{DNA sequence and deduced products of ara genes}

Appropriate restriction fragments, selected on the basis of the physical maps of pSNL1, pSNL9, pSS3, pTN13 and pSN5, were subcloned into M13mp18 and M13mp19 and used as templates to determine the nucleotide sequence of the $11 \mathrm{~kb}$ DNA region shown in 
Fig. 1. Sequence analysis revealed the presence of nine ORFs; the first three, by their position in the sequenced fragments of pSNL1 and pSNL9 and according to our previous results (Sá-Nogueira \& Lencastre, 1989), were identified as ara $A$, araB and $\operatorname{araD}$ (Fig. 1). araA, araB and araD could encode 496, 560 and 229 aa products of $56.2,60.9$ and $25.7 \mathrm{kDa}$, respectively. The six ORFs found downstream from araD, here named araL, $M, N$, $P, Q$ and $a b f A$ (Fig. 1), of 269, 394, 433, 313, 281 and 499 codons, are capable of encoding putative products of 29 , $43 \cdot 1,48 \cdot 7,35,31 \cdot 8$ and $57 \mathrm{kDa}$, respectively. All ORFs are preceded by strong ribosome binding sites with the exception of araL which possesses a weak ribosome binding site. The intercistronic regions are very short and overlaps were observed between the araD and araL coding sequences, and between araL and araM, suggesting translational coupling. Two potential hairpin-loop structures, situated next to the UAA stop codon of $a b f A$ ( $T_{1}$ and $T_{2}$, Fig. 1 , with $\Delta G$ values of -27.4 and $-18.7 \mathrm{kcal} \mathrm{mol}^{-1}$, respectively, according to Tinoco et al., 1973), probably correspond to transcription terminators. The absence of transcriptional signals among the nine coding regions suggested that they form a large operon transcribed from a promoter (described below) positioned 104 nt upstream from the araA start codon (Fig. 1).

Comparison of the primary structures of the products predicted to be encoded by the ara genes with GenBank sequences revealed significant similarities with other bacterial proteins of known function and the results are summarized in Table 2. The putative product of araM, a hydrophilic protein, did not show any significant similarity. The ara $A$, ara $B$ and $a r a D$ gene products exhibited a high level of identity to the L-arabinose isomerase, L-ribolukinase and L-ribulose-5-phosphate 4epimerase, respectively, of E. coli and Salmonella typhimurium. The product of araL, a hydrophilic protein, displayed similarity to the nagD gene product of unknown function, which belongs to the nag regulon of $E$. coli involved in the metabolism of $N$-acetyl glucosamine (Plumbridge, 1989). The $\mathrm{N}$-terminal region of the predicted sequence also shared $28.1 \%$ and $29 \cdot 2 \%$ identity (over 121 and 106 aa, respectively, data not shown) with two 4-nitrophenylphosphatases, Pho2 and Pho13, from Schizosaccharomyces pombe (Yang et al., 1991) and Saccharomyces cerevisiae (Kaneko et al., 1989), respectively.

The predicted primary structure of araN showed similarity to known sugar-binding proteins that belong to the family of binding-protein-dependent transport systems (Table 2). Although the identity was not very high, there was significant sequence conservation within the N-terminal region of these proteins which display a signature sequence, according to Tam \& Saier (1993). On the basis of this signature sequence (Fig. 2a) AraN can be included in the cluster 1 binding proteins (according to Tam \& Saier, 1993), together with the above-mentioned proteins involved in the transport of malto-oligosaccharides and multiple sugars. The hydropathy profile of AraN indicated that it is mainly a (a)

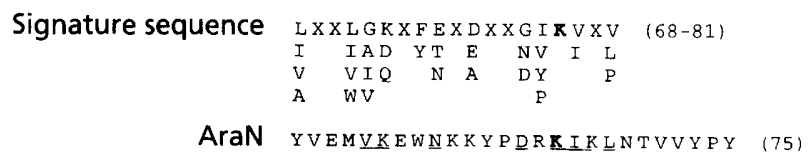

(b)

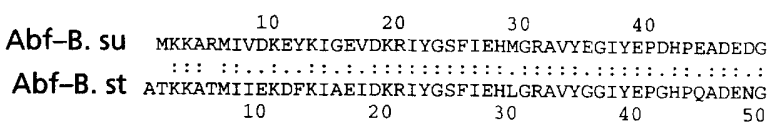

Fig. 2. (a) Alignment of a segment of the predicted sequence of the AraN protein with the signature sequence of cluster 1 binding proteins, from binding-protein-dependent transport systems, according to Tam \& Saier (1993). Numbers in parentheses indicate the positions of the last amino acid residues. The highly conserved lysine residue $(K)$ is in bold and the amino acid residues that match the signature sequence are underlined. (b) Alignment of the $\mathrm{N}$-terminal sequence (deduced from the nucleotide sequence) of AbfA from $B$. subtilis (B. su) with the $N$-terminal sequence of $\alpha$-L-arabinofuranosidase from B. stearothermophilus (B. st). Double dots represent identical amino acids and single dots represent conservative changes.

hydrophilic protein; however its $\mathrm{N}$-terminal region displayed characteristics of signal peptides of secretory precursor proteins: a positively charged $\mathrm{N}$ terminus, a hydrophobic core and a sequence, IAGCSA (starting at aa 19), which corresponds to the consensus sequence for the precursors of lipoproteins (reviewed in Hayashi \& Wu, 1990).

The predicted products of araP and araQ exhibited hydropathy profiles (according to Kyte \& Dootlittle, 1982) characteristic of integral membrane proteins: six major regions of high hydrophobicity (hydropathic index $>1 \cdot 0$ ), each composed of at least 20 aa which could be capable of spanning the membrane (Fig. 3a). AraP and AraQ shared an identity of $19 \cdot 6 \%$ and showed significant similarity with integral cytoplasmic membrane proteins involved in prokaryotic binding-proteindependent transport systems (Table 2). In common with most of these integral membrane proteins, AraP and AraQ have a conserved hydrophilic segment (Fig. 3b) at approximately 100 residues from the $C$ terminus with the consensus EAA---G---------I-LP (Dassa \& Hofnung, 1985). Furthermore, on the basis of this signature sequence, they can be included in the disaccharide subcluster proposed by Saurin et al. (1994) together with the above-mentioned proteins involved in the transport of malto-oligosaccharides, multiple sugars and $\alpha$-glycerol phosphate.

The deduced product of $a b f A$, a hydrophilic protein, displays a $\mathrm{N}$-terminal region (Fig. $2 \mathrm{~b}$ ) which resembles a signal peptide of exoproteins (reviewed on Gierasch, 1989 and Nagarajan, 1993): a positively charged $N$ terminus, a hydrophobic core and a potential cleavage site (AV, position 32-33, Fig. 2b). The primary structure of the putative product of $a b f A$ is closely related to the 
(a) AraP
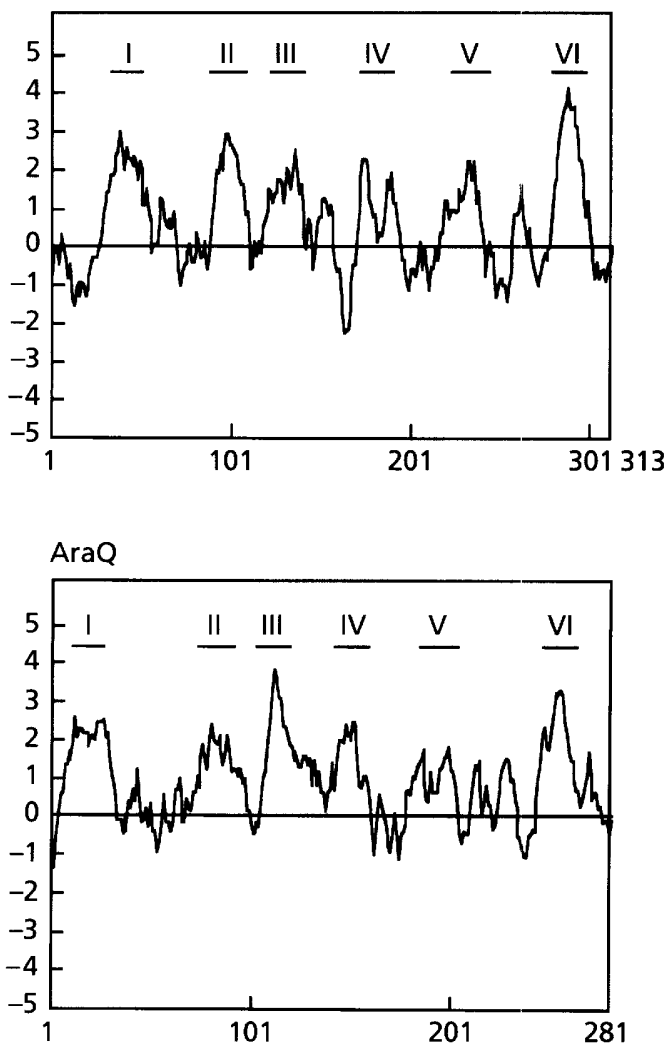

(b)

$$
\begin{aligned}
& \text { AraP } 198 \text { GLQNVPKELYEAADIDGANTMKKFLHITLPFLKPYTVYVL (109) } \\
& \text { Consensus ALQSIPDSLIEAAKIDGAGPFQRFWNIVLPLLKPVLAVLI } \\
& \text { AraQ } 165 \text { YALGLPRDLLDSARMDGCTEFGIFFRIMAPLMKPAFGAMI (100) }
\end{aligned}
$$

Fig. 3. (a) Hydropathic index for the deduced amino acid sequences of AraP and AraQ according to the algorithm of Kyte \& Doolittle (1982). The hydropathy profiles are plotted from the $\mathrm{N}$ terminus to the $\mathrm{C}$ terminus by averaging hydropathy values over a window of 10 residues. Hydrophobic segments which could correspond to membrane-spanning regions are labelled I-VI. (b) Alignment of a hydrophilic segment, at approximately 100 residues from the $C$ terminus of the predicted sequences of AraP and AraQ, with the consensus sequence for the group of integral cytoplasmic membrane proteins from binding-proteindependent transport systems (Saurin et al., 1994), which includes permeases involved in the transport of disaccharides and glycerol phosphate. The general consensus for integral membrane proteins from binding-protein-dependent permeases, EAA---G--------I-LP, where (-) represents any amino acid (Dassa \& Hofnung, 1985), is underlined. The distance of the invariant glycine residue from the $C$ terminus is represented in parentheses. Double dots represent identical amino acids and single dots represent conservative changes.

$\alpha$-L-arabinofuranosidase of Streptomyces lividans (Table 2) and the N-terminal region (Fig. 2b) is $74 \%$ identical and $96 \%$ similar to the sequenced $\mathrm{N}$ terminus of purified $\alpha$-L-arabinofuranosidase from Bacillus stearothermophilus (Gilead \& Shoham, 1995). These observations strongly suggest that abfA encodes an $\alpha$-Larabinofuranosidase.

\section{RNA transcript analysis of the t-arabinose gene region}

Total RNA from cells grown in the presence and absence of L-arabinose was isolated, blotted and hybridized to three different DNA probes (probes 1, 2 and 3, Fig. 1) each specific to one gene of the ara region (araA, araM and $a b f A$, respectively). Northern blot analysis (Fig. 4) revealed that ara genes are organized in a large polycistronic operon, and that transcripts could be detected only if the cells were grown in the presence of $\mathrm{L}$-arabinose. In addition to a transcript of $11 \mathrm{~kb} c o m-$ prising all genes and detected with the three probes, several other signals of different intensities were obtained depending on the probe used (Fig. 4). Using the ara $A$-specific probe, we detected five different transcripts of about $8 \cdot 2,6 \cdot 4,5 \cdot 8,4$ and $1.9 \mathrm{~kb}$, considering a margin of error of $10-15 \%$ for the size determination of transcripts. Two additional transcripts of about 8.2 and $6.4 \mathrm{~kb}$ were visualized with the araM-specific probe and three hybridization signals were obtained with the abf $A$ specific probe: $8 \cdot 3,4 \cdot 8$ and $1 \cdot 1 \mathrm{~kb}$. Interestingly, stable secondary structures were identified at the corresponding sites within the $\operatorname{araB}$, araL, araN and $\operatorname{araQ}$ sequences (Fig. 1). The exact nature of these different minor transcripts is unknown but they might be generated by premature transcription termination and/or processing of the multicistronic messenger or RNA degradation. Another possible explanation is the presence of transcription initiation sites located downstream from the promoter defined by primer extension analysis (see below).

\section{The promoter region and transcriptional start site of the ara operon}

To determine the transcriptional start site of the ara operon, total RNA was extracted during the exponential growth of wild-type cultures in the presence and in the absence of $\mathrm{L}$-arabinose. Reverse transcripts were obtained using an end-labelled 17-mer (primer B, Fig. 1), designed to hybridize to part of the araA mRNA. A single extension product was detected with RNA isolated from cells grown in the presence of $\mathrm{L}$-arabinose, the size of which suggests that transcription of the ara operon starts at a $G$ residue situated $97 \mathrm{nt}$ upstream from the araA start codon (Fig. 5). No extension product was seen when RNA was isolated from cells grown in the absence of L-arabinose. The same transcription start point was obtained using a second primer (primer A, Fig. 1) designed to hybridize to part of the mRNA 50 bases upstream from the first primer (Fig. 5). The synthesis of the ara operon mRNA is induced by Larabinose and driven by a strong promoter as evaluated by the intensity of the reverse transcript signal obtained. Situated 7 and $30 \mathrm{bp}$ upstream from the ara operon transcription start site are sequences identical to the consensus -35 and -10 regions (TTGACA-17 bpTATAAT), respectively, of promoters recognized by $B$. subtilis $\sigma^{\mathrm{A}}$-containing RNA polymerase (Moran et al., 1982). Sequence analysis of the promoter region revealed the existence of three inverted repeats, putative 
(a)

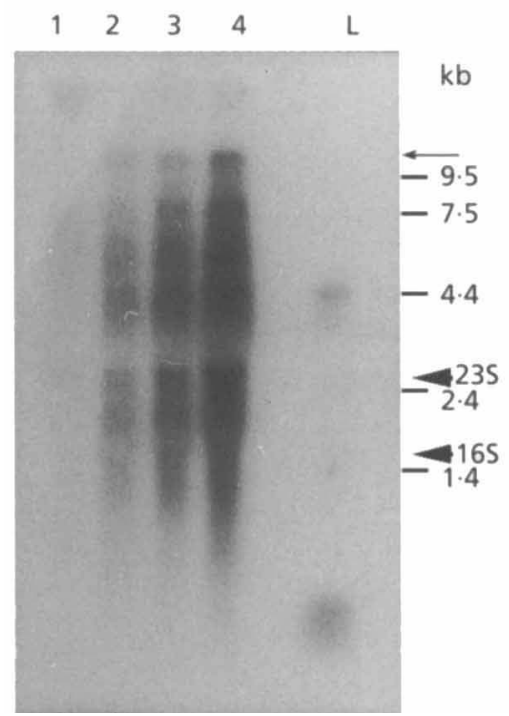

(b)

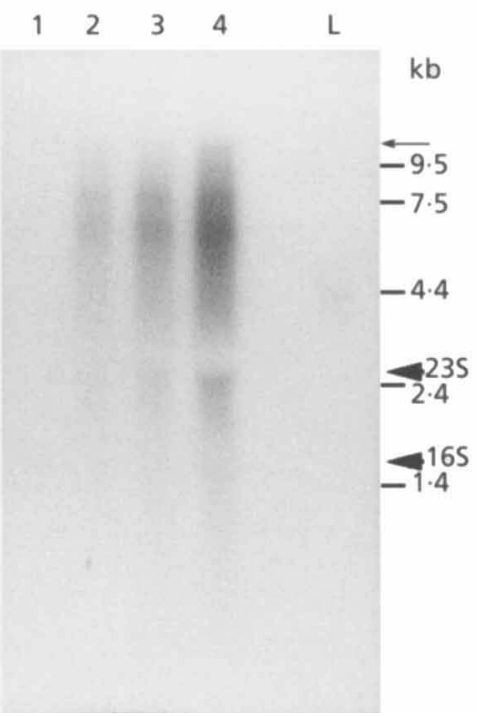

(c)

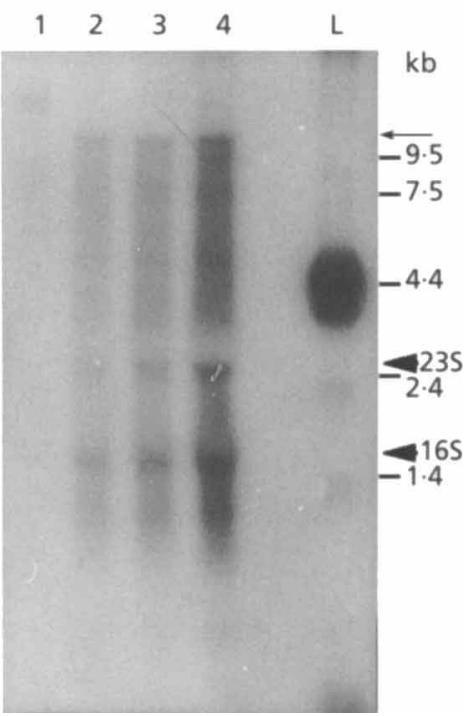

Fig. 4. Northern analysis of the ara operon-specific transcripts. Lanes: $1,10 \mu \mathrm{g}$ total RNA extracted from the uninduced wild-type strain B. subtilis $168 \mathrm{~T}^{+} ; 2,3$ and $4,2.5 \mu \mathrm{g}, 5 \mu \mathrm{g}$ and $10 \mu \mathrm{g}$, respectively, of total RNA extracted from the induced wild-type strain B. subtilis $168 \mathrm{~T}^{+}$grown on L-arabinose (see Methods); L, $4 \mu \mathrm{g}$ RNA ladder (0.24-9.5 kb; Gibco/BRL). The samples were run in $1 \%(\mathrm{a}, \mathrm{b})$ and $1.2 \%(\mathrm{c})$ agarose formaldehyde denaturing gel. The ${ }^{32} \mathrm{p}$-labelled probes used were synthesized from (a) a $1.6 \mathrm{~kb}$ EcoRI-Pstl fragment (position 249-1897, probe 1), (b) a $0.8 \mathrm{~kb}$ Ncol-EcoRV fragment (position 5270-6079, probe 2) and (c) a $0.7 \mathrm{~kb}$ Pstl-Aval fragment (position 9538-10275, probe 3). The RNA ladder was probed with ${ }^{32}$ P-labelled $\lambda$ DNA and also visualized by staining with ethidium bromide. The transcript of about $11 \mathrm{~kb}$ comprising all genes and detected with the three probes is indicated by an arrow.

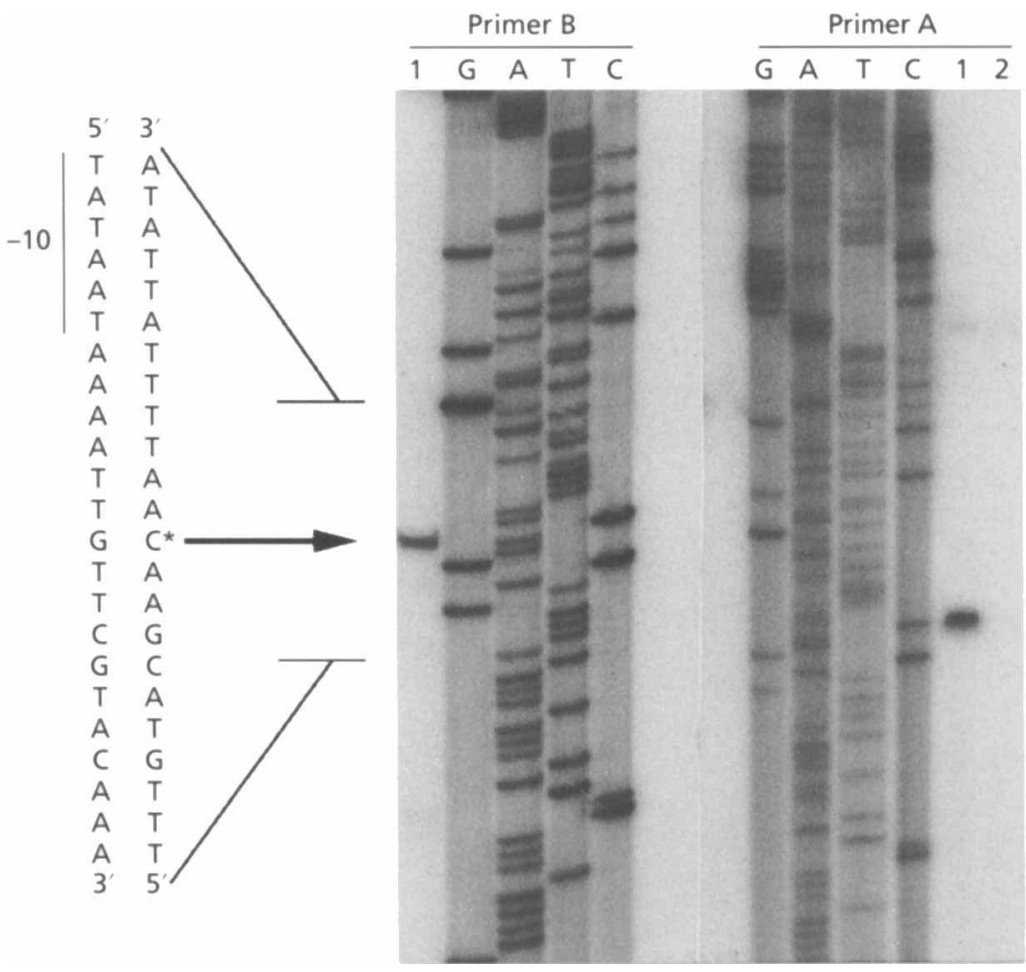

Fig. 5. Primer extension analysis of the ara operon promoter. Two radiolabelled oligonucleotide primers, $A$ and $B$, complementary to two different regions downstream from the araABD promoter [primer A, 5' GAAGCATGTAAACTGCCCC 3', complementary to a region of araA mRNA located between nucleotides 216 and 234 (Fig. 1) and B, 5' CCAGCGTCTCTTCCCCG 3', complementary to a region of the $a r a A$ mRNA located between nucleotides 283 and 300 (Fig. 1)] were hybridized with $B$. subtilis BR151 RNA isolated from exponentially growing cells in the presence (lane 1) or absence (lane 2) of L-arabinose. After extension, the products were analysed by gel electrophoresis, together with a set of dideoxynucleotide chain-termination sequencing reactions using the same primers and a single-stranded M13 DNA template which includes the entire ara $A$ gene and an additional $228 \mathrm{bp}$ of its ' 5 ' flanking sequence.

operator-like sequences, in the -35 and -10 regions (Fig. 1). A potential hairpin-loop structure with a $\Delta G$ value of $-19 \cdot 2 \mathrm{kcal} \mathrm{mol}^{-1}$ (Tinoco et al., 1973), centred
27 bp upstream from the -35 region (Fig. 1), probably corresponds to a transcription terminator of a gene located upstream from the cloned DNA fragment. 

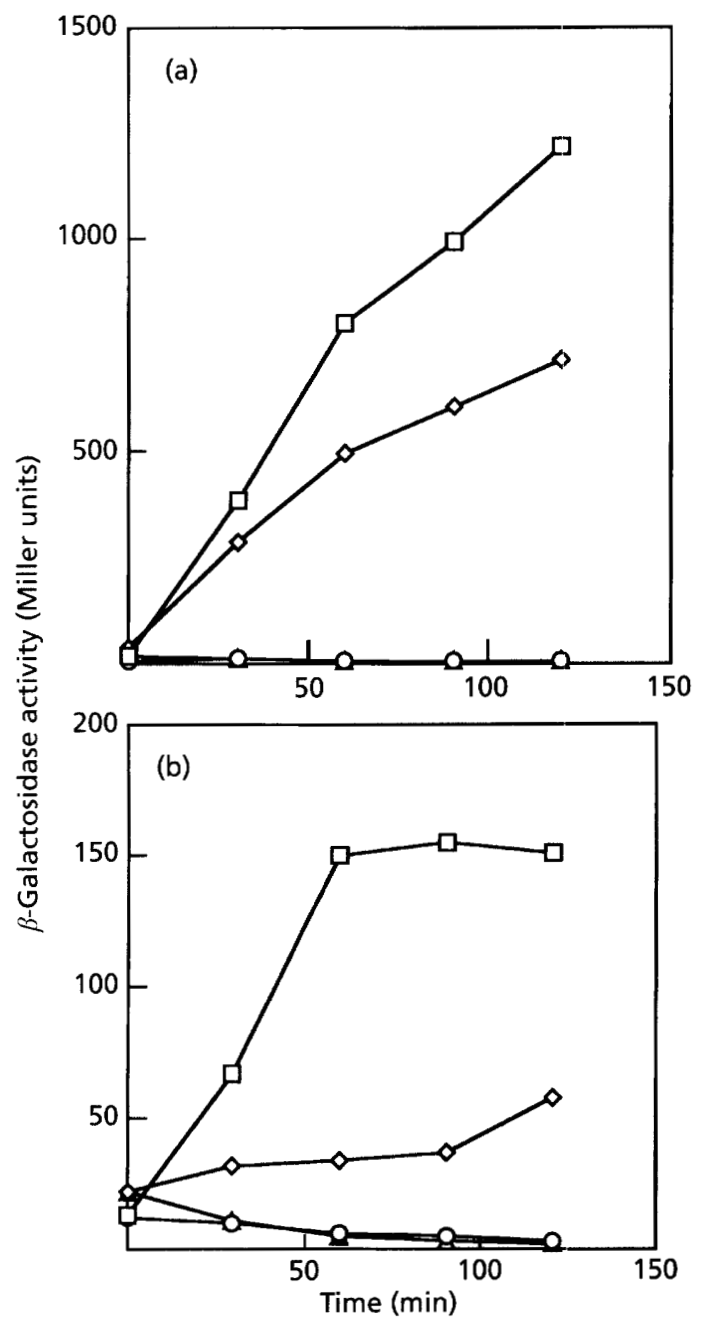

Fig. 6. Expression of the ara operon measured by determination of the levels of $\beta$-galactosidase activity (Miller units) present in exponentially growing cells. Strains of $B$. subtilis harbouring transcriptional lacZ fusions were grown on minimal $C$ medium supplemented with $1 \%$ casein hydrolysate and either (a) $0.4 \%$ L-arabinose or (b) $0.4 \%$ L-arabinose plus $0.4 \%$ glucose (see Methods). Time is expressed in minutes after induction. $\diamond$, IQB101 (araB'-lacZ erm; $\mathrm{Ara}^{-} \mathrm{Em}^{\mathrm{r}} \mathrm{LaCZ}^{+}$); $\square$, IQB 103 (araA'-lacZ cat; $\mathrm{Ara}^{+} \mathrm{Cm}^{r} \mathrm{LacZ}^{+}$); $\triangle$, IQB 102 (araB'-erm lacZ; $\mathrm{Ara}^{-} \mathrm{Em}^{\mathrm{r}} \mathrm{LaCZ}^{-}$; negative control); O, IQB104 (araA'-cat lacZ; $\mathrm{Ara}^{+} \mathrm{Cm}^{r} \mathrm{LacZ}^{-}$; negative control). For each strain the results represent the mean, in Miller units, of two independent experiments.

\section{Expression of the ara operon is induced by t-arabinose and repressed by glucose}

To study the regulation of expression of the operon we constructed transcriptional lacZ fusions at this locus. The replicative plasmids pSNL11 and pSNL12, carrying lacZ and erm (Fig. 1), were linearized and used separately to transform the wild-type $168 \mathrm{~T}^{+}$strain. This resulted in the integration of lacZ and $\mathrm{erm}$ into the chromosome at the $a r a B$ locus. The resulting strains, IQB101 (araB'-lacZ erm) and IQB102 (araB'-erm lacZ), were unable to grow on $\mathrm{L}$-arabinose as sole carbon source, which confirmed the insertional inactivation of
araB. The integrational plasmids pSNL13 and pSNL14, carrying the same DNA fragment in opposite orientations (Fig. 1), were integrated as single copy into the chromosome of the wild-type strain $168 \mathrm{~T}^{+}$. The resulting strains, IQB103 (araA'-lacZ cat) and IQB104 (ara $A^{\prime}-$ cat lac $Z$ ), respectively, displayed an $\mathrm{Ara}^{+}$phenotype because the integration was not disruptive. The LacZ phenotype of the four strains was tested on minimal $C$ medium plates supplemented with $1 \%$ casein hydrolysate and X-Gal. Upon addition of L-arabinose to the medium, strains IQB101 and IQB103 presented a dark blue phenotype, whereas those of IQB102 and IQB104 remained white, confirming that the expression of the operon is driven from a promoter located upstream from ara $A$ and induced by $\mathrm{L}$-arabinose. Furthermore, addition of other pentoses such as Dxylose and D-ribose failed to induce a $\mathrm{LacZ}^{+}$phenotype in strain IQB103. The regulation of ara operon expression was examined in cultures during midexponential phase in minimal $\mathrm{C}$ medium supplemented with $1 \%$ casein hydrolysate as described in Methods. The levels and patterns of lacZ expression in IQB101 (araB'-lacZ erm; $\mathrm{Ara}^{-} \mathrm{LacZ}^{+}$), IQB103 (araA'-lacZ cat; $\mathrm{Ara}^{+} \mathrm{LacZ}^{+}$), IQB102 (araB'-erm lacZ; $\mathrm{Ara}^{-}$ $\mathrm{LacZ}^{-}$; negative control) and IQB104 (ara $A^{\prime}-$ cat lacZ; $\mathrm{Ara}^{+} \mathrm{LacZ}^{-}$; negative control) determined in the presence of $\mathrm{L}$-arabinose and $\mathrm{L}$-arabinose plus glucose are shown in Fig. 6. When the four strains were grown in the absence of inducer, the level of accumulated $\beta$ galactosidase activity, at time $t=120 \mathrm{~min}$, was $4 \cdot 4,4 \cdot 8$, 2.8 and 1.8 Miller units, respectively. In the presence of $\mathrm{L}$-arabinose the pattern of expression observed in strains IQB101 ( $a r a B^{\prime}-l a c Z ; A^{-}$) and IQB103 ( $a r a A^{\prime}-l a c Z$; $\mathrm{Ara}^{+}$) was very similar (Fig. 6) but the levels of accumulated $\beta$-galactosidase activity in the araB null mutant were less than $60 \%$ relative to the wild-type strain (discussed below). Addition of glucose reduced the level of expression to less than $12 \%$ in both $\mathrm{Ara}^{+}$and Ara $^{-}$backgrounds (Fig. 6). These data demonstrate that L-arabinose is an inducer which stimulates the expression of the ara operon at the transcriptional level and transcription is subjected to catabolite repression by glucose. Furthermore, the prediction that the expression of the ara operon is driven from a strong promoter, made on the basis of the intensity of the reverse transcript signal observed in primer extension analysis, was confirmed when $\beta$-galactosidase activity was measured in strain IQB103 (araA $A^{\prime}$ cat lacZ; $\mathrm{Ara}^{+}$).

\section{araL, $M, N, P, Q$ and abfA are not required for L-arabinose utilization}

Strains IQB202 and IQB204 in which the integration of plasmids pSS2 and pTN10, respectively, interrupted the transcription unit at araL and araN (Fig. 1), exhibited an $\mathrm{Ara}^{+}$phenotype, however, their growth on minimal medium plates with L-arabinose as sole carbon source was slightly slower than the one observed with the wildtype strain $168 \mathrm{~T}^{+}$. This phenotype was not observed with strain IQB205 in which pTN13 disrupted the operon at the end of $\operatorname{ara} Q$. To confirm that $\operatorname{araL}, M, N$, 
$P, Q$ and $a b f A$ are not required for $\mathrm{L}$-arabinose utilization, we constructed a deletion in the region downstream from araD by replacing in vitro the wildtype sequences of $\operatorname{araL}, M, N, P, Q$ and $a b f A$ with a $\mathrm{Sp}^{\mathrm{r}}$ cassette and then using it to replace the corresponding chromosomal sequences (see Methods). Plasmid pSN22 (Fig. 1) was linearized and used to transform the wildtype strain $168 \mathrm{~T}^{+} \mathrm{Sp}^{\mathrm{r}}$. The resulting strain IQB206, was $\mathrm{Km}^{\mathrm{s}}$ which indicated that the $\mathrm{Sp}^{\mathrm{r}}$ phenotype was the result of a double cross-over event that occurred on both sides of the cassette inserted between the araL and $a b f A$ sequences (Fig. 1). This mutant strain was able to grow on minimal medium plates with L-arabinose but displayed a phenotype even more drastic than the one exhibited with strains IQB202 and IQB204. To quantify this observation we determined the specific growth rate of the deletion-insertion mutant and the wild-type strain in liquid minimal $\mathrm{C}$ medium with $\mathrm{L}$-arabinose as sole carbon source, as described in Methods. The doubling time of strain IQB206 was 1.8-fold higher than the wildtype strain $168 \mathrm{~T}^{+}, 193.4 \pm 7 \cdot 2$ and $107.7 \pm 3.6 \mathrm{~min}$ (means of three independent experiments \pm SEM), respectively. These results confirmed that the genes located downstream from araD in the operon are not essential for L-arabinose utilization, however their absence in the deletion mutant affects the specific growth rate in minimal medium with L-arabinose as the sole carbon source when compared to the wild-type strain.

\section{DISCUSSION}

In this study we have described a new catabolic operon involved in the utilization of $\mathrm{L}$-arabinose in B. subtilis, which we designated ara. The arabinose metabolic genes $\operatorname{ara} A$, araB and $\operatorname{araD}$, encoding $\mathrm{L}$-arabinose isomerase, L-ribulokinase and L-ribulose-5-phosphate 4epimerase, respectively, were cloned previously and by complementation experiments the products of $a r a B$ and araD were shown to be functionally homologous to their E. coli counterparts (Sá-Nogueira \& Lencastre, 1989). These genes, whose inactivation leads to an $\mathrm{Ara}^{-}$ phenotype, were found to be the first three ORFs of a nine cistron transcriptional unit whose total length is $11 \mathrm{~kb}$. To our knowledge this operon is the largest catabolic operon described in B. subtilis. As expected from the occurrence of genetic complementation, the deduced products of araA, araB and araD from $B$. subtilis display a very high level of identity to the corresponding enzymes from E. coli and Sal. typhimurium, which indicates that this metabolic pathway was fundamentally conserved during evolution. In $B$. subtilis the metabolic gene order, ara $A B D$, coincides with the order of the enzymic steps carried out by the proteins they encode. This order is different from the one found in the operons of the Enterobacteriaceae members E. coli and Sal. typhimurium, araBAD, so it seems that the three genes did not act as a unitary block in the evolution of the eubacterial ara genes.

The six ORFs found downstream from araD, here named araL, $M, N, P, Q$ and $a b f A$, are not required for L-arabinose utilization. This was shown in a mutant strain, IQB206, bearing a deletion in the region downstream from araD comprising all genes. The function of araL and araM is unknown. The putative product of araM did not show any significant similarity with other bacterial proteins of known function and the weak similarities displayed by araL did not suggest any particular function. Interestingly, the $\mathrm{N}$-terminal sequence of araL shares an identity of $18.7 \%$ over 193 residues with the $\mathrm{C}$-terminal sequences of araM (data not shown). The primary sequences of the products of araN, araP and araQ strongly suggest that they have a similar function to that of a superfamily of membranebound nutrient transport systems (Higgins et al., 1990). Sequence similarities to known import proteins and the organization of the genes in the operon revealed the presence of three components of these transport systems. Firstly, the $\mathrm{N}$ terminus of AraN has a predicted signal peptide and sequences typical of Gram-positive lipoproteins (IAGCSA, starting at aa 19). We therefore suggest that AraN might be anchored in the cytoplasmic membrane via an amino-lipid group (Gilson et al., 1988; Perego et al., 1991). Secondly, araP and araQ gene products, as other characterized integral cytoplasmic membrane proteins, have hydropathy profiles which are virtually superimposable and some of their residues are apparently conserved (Fig. 3). Finally, araN, araP and araQ belong to the same operon and the ligand-specific binding protein, AraN, is encoded by the promoterproximal gene, a situation common to these systems. In $B$. subtilis the phosphotransferase system is not involved in the transport of L-arabinose into the cell (Gay et al., 1973). Therefore, it is tempting to propose that AraN, AraP and AraQ are components of a high affinity transport system for L-arabinose. However, no evident ATP-binding protein connected with energy coupling of the transport system was found in the operon.

The transport of L-arabinose across the E. coli cytoplasmic membrane requires the expression of either the high-affinity transport operon, araFGH, a bindingprotein-dependent system (Horazdovsky \& Hogg, 1989; Kolodrubetz \& Schleif, 1981) or the low-affinity transport operon, araE, a proton symporter (Novotny $\&$ Englesberg, 1966). The existence of two parallel uptake systems thwarts usual genetic attempts to isolate mutants defective in either of the transport systems. The $\mathrm{Ara}^{+}$phenotype displayed by the $B$. subtilis deletioninsertion mutant strain IQB206 ( $\triangle a r a-a b f A:: s p c)$ together with the 1.8 -fold increase in doubling time observed on liquid minimal medium with L-arabinose as the sole carbon source, relative to the wild-type strain, is typical of a transport mutant when the micro-organism has alternative transport systems for the same substrate. An additional explanation for this phenotype observed in the deletion-insertion mutant is that insertion of $s p c$ might result in a less stable mRNA encoding $\operatorname{ara} A B D$, leading to decreased amounts of their products. Interestingly, the primary structure of AraP and AraQ showed weak similarity with $\mathrm{AraH}$, the integral cytoplasmic membrane protein from E. coli, and the same result was observed between AraN and AraF, the E. coli 
arabinose binding protein (data not shown). Furthermore, on the basis of their signature sequences, AraN, AraP and AraQ can be included in the disaccharide subcluster (Figs 2 and 3) together with proteins involved in the high-affinity transport of malto-oligosaccharides and multiple sugars. B. subtilis secretes three enzymes involved in the degradation of $\mathrm{L}$-arabinose polymers, an endo-arabanase and two arabinosidases, and the purified endo-arabanase has been shown to be capable of releasing arabinosyl oligomers from plant cell walls (Kaji \& Saheki, 1975; Weinstein \& Albersheim, 1979). To account for these observations a wider substrate range, L-arabinose and/or L-arabinose oligomers, for the $B$. subtilis AraN binding protein is suggested. The last gene of the ara operon, $a b f A$, probably encodes a $\alpha$ $\mathrm{L}$-arabinofuranosidase, based on the strong similarity observed between the primary structure of its putative product and other bacterial arabinosidases. Whether this enzyme is extracellular or intracellular is unknown.

Expression of the ara operon is induced by L-arabinose and driven by a promoter located upstream of araA. This has been demonstrated in this study by Northern blotting and primer extension analysis. Examination of the ara operon promoter reveals -35 and -10 sequences, relative to its transcriptional start site (shown in Fig. 1), separated by an optimal spacing of $17 \mathrm{bp}$, identical to the consensus sequences derived from the analysis of many $\sigma^{\mathrm{A}}$-dependent promoters (Moran $e t$ al., 1982). These sequences were shown to be important for the interaction of $\sigma^{\mathrm{A}}$ with their cognate promoters (reviewed in Moran, 1993). The presence of a strong promoter raises the possibility that transcription of ara is negatively regulated like in other well characterized $B$. subtilis catabolic operons, such as $x y l$ (Gärtner et al., 1992) and gnt (Fujita \& Fujita, 1987); in fact the product of $\mathrm{araC}$ recently cloned, is a negative regulator of the ara operon (I. Sá-Nogueira \& L. J. Mota, unpublished). To characterize the regulation of ara expression in greater detail we constructed transcriptional fusions of the ara promoter to the E. coli lacZ gene in $\mathrm{Ara}^{+}$and $\mathrm{Ara}^{-}$ strains. The induction by L-arabinose in the $\mathrm{Ara}^{+}$ background was approximately 100 -fold and the pattern of expression observed in $\mathrm{Ara}^{-}$and $\mathrm{Ara}^{+}$strains was very similar. Interestingly however, the levels of accumulated $\beta$-galactosidase activity in the $\mathrm{Ara}^{-}$background were less than $60 \%$ of the fully induced level in the wildtype strain. Since in this strain the ara transcription unit is interrupted at the level of $\operatorname{araB}$ (Fig. 1), and a role in the transport of L-arabinose was proposed for the downstream genes $\operatorname{araN}$, araP and $a r a Q$, this effect could be due to less accumulated intracellular Larabinose which prevents full expression of the ara promoter. Another possible explanation is that the products of araL and araM could stimulate transcription from the ara promoter. Addition of glucose reduced the level of expression to less than $12 \%$ in both $\mathrm{Ara}^{+}$and $\mathrm{Ara}^{-}$backgrounds, indicating that repression of the ara operon by glucose acts at the transcriptional level.

The regulatory system mediating catabolite repression in B. subtilis seems to be accomplished by a negative regulatory mechanism (reviewed in Hueck \& Hillen, 1995; Saier et al., 1996). This evidence is based on the location and the sequences of cis-acting sites (CREs) responsible for catabolite repression of several B. subtilis genes and operons. Moreover, catabolite repression of most genes regulated via these cis-acting sites is also affected by the trans-acting factors CcpA, a DNAbinding protein, and $\mathrm{HPr}$, an intermediate in the phosphotransferase sugar transport system. It has been proposed that HPr-Ser-P might interact with CcpA and that this interaction might allow CcpA to bind to the CRE (Deutscher et al., 1994). Strong evidence for this proposal, but also contradictory results, have been obtained recently (Saier et al., 1996; and references therein). CREs of catabolic genes and operons are located either in the promoter regions, where the binding of a regulatory protein probably interferes with transcription initiation, or in the downstream regions (reviewed in Hueck \& Hillen, 1995). In the case of the hut operon two active CREs were found, one at the promoter and the other within butP, and a looping mechanism involving co-operatively bound CREs has been proposed to interfere with transcription initiation (Wray et al., 1994). Furthermore, the transition-state regulator $\mathrm{AbrB}$ is capable of specifically binding to but $C R E$ in vitro and an $a b r B$ null mutation leads to more efficient catabolite repression of some genes in $B$. subtilis, including $\mathrm{L}$-arabinose isomerase. Thus, $\mathrm{AbrB}$ has been suggested to compete for binding to CRE with CcpA (Fisher et al., 1994). The promoter region of the ara operon contains a sequence very similar to the CRE consensus sequence (TGWNANCGNTNWCA; W = A, T; Weickert \& Chambliss, 1990) located between the transcription start site and the translation start site of araA (position 191-204, Fig. 1). A second sequence, which shows weak similarity with the CRE consensus sequence was found within ara $A$ (position 260-273, Fig. 1). Since inducer exclusion does not play a major role in carbon regulation of expression of the ara metabolic genes (Sá-Nogueira et al., 1988), as observed in the hut operon (Chasin \& Magasanik, 1968), it will thus be interesting to investigate the role of $\mathrm{CcpA}, \mathrm{HPr}$ and $\mathrm{AbrB}$ in the catabolite repression of the ara operon and whether these sequences are cis-acting sites responsible for catabolite repression of the ara genes.

\section{ACKNOWLEDGEMENTS}

We would like to thank Drs M. Debarbouillé, Adriano O. Henriques, Helena Paveia for helpful discussions and A. O. Henriques and C. P. Moran Jr for the gift of plasmids. T. V. Nogueira was the recipient of a fellowship from Junta Nacional de Investigação Científica e Tecnológica (JNICT). This work was supported by grants 87.218 / Bio and 1287/ 92/Bio, from Junta Nacional de Investigação Científica e Tecnológica (JNICT).

\section{REFERENCES}

Anagnostopoulos, C. \& Spizizen, J. (1961). Requirements for transformation in Bacillus subtilis. J Bacteriol 81, 741-746. 
Chasin, L. A. \& Magasanik, B. (1968). Induction and repression of the histidine-degrading enzymes of Bacillus subtilis. J Biol Chem 243, 5165-5178.

Dale, R. M. K., McClure, B. A. \& Houchins, J. P. (1985). A rapid single-stranded cloning strategy for producing a sequential series of overlapping clones for use in DNA sequencing: application to sequencing the corn mitochondrial $18 \mathrm{~S}$ rDNA. Plasmid 13, 31-40.

Dassa, E. \& Hofnung, M. (1985). Sequence of mal G gene in E. coli $\mathrm{K} 12$ : homologies between integral membrane components from binding protein-dependent transport systems. EMBO J 4, 2287-2293.

Debarbouillé, M., Arnaud, M., Foust, A., Klier, A. \& Rapoport, G. (1990). The sacT gene regulating the sacPA operon in Bacillus subtilis shares strong homology with transcriptional antiterminators. J Bacteriol 172, 3966-3973.

Deutscher, J., Reizer, J., Fischer, C., Galinier, A., Saier, M. H., Jr \& Steinmetz, M. (1994). Loss of protein kinase-catalyzed phosphorylation of $\mathrm{Hpr}$, a phospho-carrier protein of the phosphotransferase system, by mutation of the $p t s H$ gene confers catabolite repression resistence to several catabolic genes of $B$. subtilis. J Bacteriol 176, 3336-3344.

Englesberg, E., Squires, C. \& Meronk, F. (1969). The arabinose operon in Escherichia coli $\mathrm{B} / \mathrm{r}$ : a genetic demonstration of two functional states of the product of a regulatory gene. Proc Natl Acad Sci USA 80, 6790-6794.

Ferrari, E., Nguyen, A., Lang, D. \& Hoch, J. (1983). Construction and properties of an integrable plasmid for Bacillus subtilis. $J$ Bacteriol 154, 1513-1515.

Fisher, S. H., Strauch, M. A., Atkinson, M. R. \& Wray, L. V., Jr (1994). Modulation of Bacillus subtilis catabolite repression by transition state regulatory protein AbrB. I Bacteriol 176, 1903-1912.

Fujita, Y. \& Fujita, T. (1987). The gluconate operon gnt of Bacillus subtilis encodes its own transcriptional negative regulator. Proc Natl Acad Sci USA 84, 4524-4528.

Gärtner, D., Degenkolb, J., Rippberger, J., Allmansberger, R. \& Hillen, W. (1992). Regulation of Bacillus subtilis W23 xylose utilization operon: interaction of Xyl repressor with $x y l$ operator and the inducer xylose. Mol Gen Genet 232, 415-422.

Gay, P., Cordier, P., Marquet, M. \& Delobbe, A. (1973). Carbohydrate metabolism and transport in Bacillus subtilis. A study of ctr mutations. Mol Gen Genet 121, 355-368.

Gierasch, L. M. (1989). Signal sequences. Biochemistry 28, 923-930.

Gilead, S. \& Shoham, Y. (1995). Purification and characterization of $\alpha$-L-arabinofuranosidase from Bacillus stearothermophilus T6. Appl Environ Microbiol 61, 170-174.

Gilson, E., Alloing, G., Schmidt, T., Claverys, J.-P., Dudler, R. \& Hofnung, M. (1988). Evidence for high-affinity binding-protein dependent systems in Gram-positive bacteria and Mycoplasma. EMBO J 7, 3971-3974.

Hayashi, S. \& Wu, H. C. (1990). Lipoproteins in bacteria. $J$ Bioenerg Biomembr 22, 451-471.

Higgins, C. F., Hyde, S. C., Mimmack, M. M., Gileadi, U., Gill, D. R. \& Gallagher, M. P. (1990). Periplasmic binding-protein dependent systems. J Bioenerg Biomemb 22, 571-592.

Horazdovsky, B. \& Hogg, R. (1989). Genetic reconstitution of the high-affinity L-arabinose operon in Escherichia coli. $J$ Bacteriol 171, 3053-3059.

Hueck, C. J. \& Hillen, W. (1995). Catabolite repression in Bacillus subtilis: a global regulatory mechanism for the Gram-positive bacteria? Mol Microbiol 15, 395-401.
Igo, M. M. \& Losick, R. (1986). Regulation of a promoter that is utilized by minor forms of RNA polymerase holoenzyme in Bacillus subtilis. J Mol Biol 191, 615-624.

Kaji, A. \& Saheki, T. (1975). Endo-arabanase from Bacillus subtilis F-11. Biochim Biophys Acta 410, 354-360.

Kaneko, Y., Toh-e, A., Banno, I. \& Oshima, Y. (1989). Molecular characterization of a specific $p$-nitrophenylphosphatase gene, PHO13, and its mapping by chromosome fragmentation in Saccharomyces cerevisiae. Mol Gen Genet 220, 133-139.

Katz, L. (1970). Selection of $a r a B$ and ara C mutants of Escherichia coli $\mathrm{B} / \mathrm{r}$ by resistance to ribitol. J Bacteriol 102, 593-595.

Kolodrubetz, D. \& Schleif, R. (1981). L-Arabinose transport systems in Escherichia coli K12. J Bacteriol 148, 472-479.

Kyte, J. \& Doolittle, R. F. (1982). A simple method for displaying the hydropathic character of a protein. J Mol Biol 157, 105-132.

Lepesant, J. A. \& Dedonder, R. (1967a). Metabolisme du Larabinose chez Bacillus subtilis Marburg Ind ${ }^{-} 168$. C R Acad Sci Ser D, 2683-2686.

Lepesant, J. A. \& Dedonder, R. (1967b). Isolement de mutants du système du L-arabinose chez Bacillus subtilis Marburg Ind ${ }^{-} 168$. C $R$ Acad Sci Ser D, 2832-2835.

Martin, I., Debarbouillé, M., Ferrari, E., Klier, A. \& Rapoport, G. (1987). Characterization of the levanase gene of Bacillus subtilis which shows homology to yeast invertase. Mol Gen Genet 208, 177-184.

Miller, J. H. (1972). Experiments in Molecular Genetics. Cold Spring Harbor, NY: Cold Spring Harbor Laboratory.

Moran, C. P., Jr (1993). RNA polymerase and transcription factors. In Bacillus subtilis and Other Gram-positive Bacteria: Biochemistry, Physiology and Molecular Genetics, pp. 653-667. Edited by A. L. Sonensheim, J. A. Hoch \& R. Losick. Washington, DC: American Society for Microbiology.

Moran, C. P., Jr, Lang, N., LeGrice, S. F. J., Lee, G., Stephens, M., Sonensheim, A. L., Pero, J. \& Losick, R. (1982). Nucleotide sequences that signal the initiation of transcription in Bacillus subtilis. Mol Gen Genet 186, 339-346.

Nagarajan, V. (1993). Protein secretion. In Bacillus subtilis and Other Gram-positive Bacteria: Biochemistry, Physiology and Molecular Genetics, pp. 713-726. Edited by A. L. Sonensheim, J. A. Hoch \& R. Losick. Washington, DC: American Society for Microbiology.

Novotny, C. \& Englesberg, E. (1966). The L-arabinose permease system in Escherichia coli B/r. Biochim Biophys Acta 117, 217-230.

Pascal, M., Kunst, F., Lepesant, J. A. \& Dedonder, R. (1971). Characterization of two sucrase activities in Bacillus subtilis Marburg. Biochem 53, 1059-1066.

Paveia, H. \& Archer, L. (1992a). Genes for L-arabinose utilization in Bacillus subtilis. Brotéria Genética Lisboa XIII (LXXX), 149-159.

Paveia, H. \& Archer, L. (1992b). Mapping of ara genes in Bacillus subtilis. Brotéria Genética Lisboa XIII (LXXX), 161-167.

Perego, M. (1993). Integrational vectors for genetic manipulation in Bacillus subtilis. In Bacillus subtilis and Other Gram-positive Bacteria: Biochemistry, Physiology and Molecular Genetics, pp. 615-624. Edited by A. L. Sonensheim, J. A. Hoch \& R. Losick. Washington, DC: American Society for Microbiology.

Perego, M., Higgins, C. F., Pearce, S. R., Gallagher, M. P. \& Hoch, J. A. (1991). The oligopeptide transport system of Bacillus subtilis plays a role in the initiation of sporulation. Mol Microbiol 5, 173-185. 
Perkins, J. B. \& Youngman, P. J. (1986). Construction and properties of $\mathrm{Tn} 917-\mathrm{lac}$, a transposon derivative that mediates transcriptional gene fusions in Bacillus subtilis. Proc Natl Acad Sci USA 83, 140-144.

Plumbridge, J. A. (1989). Sequence of the nagBACD operon in Escherichia coli $\mathrm{K} 12$ and pattern of transcription within the nag regulon. Mol Microbiol 3, 505-515.

Saier, M. H., Jr, Chauvaux, S., Cook, G. M., Deutscher, J., Paulsen, I. T., Reizer, J. \& Ye, J.-J. (1996). Catabolite repression and inducer control in Gram-positive bacteria. Microbiology 142, 217-230.

Sambrook, J., Fritsch, E. F. \& Maniatis, T. (1989). Molecular Cloning: a Laboratory Manual 2nd edn. Cold Spring Harbor, NY: Cold Spring Harbor Laboratory.

Sanger, F., Nicklen, S. \& Coulson, A. R. (1977). DNA sequencing with chain-terminating inhibition. Proc Natl Acad Sci USA 74, 140-144.

Sá-Nogueira, I. \& Lencastre, H. (1989). Cloning and characterization of $\operatorname{araA}, \operatorname{araB}$ and $a r a D$, the structural genes for $\mathrm{L}-$ arabinose utilization in Bacillus subtilis. $J$ Bacteriol 171, 4088-4091.

Sá-Nogueira, I., Paveia, H. \& Lencastre, H. (1988). Isolation of constitutive mutants for L-arabinose utilization in Bacillus subtilis. J Bacteriol 170, 2855-2857.

Saurin, W., Köster, W. \& Dassa, E. (1994). Bacterial binding protein-dependent permeases: characterization of distinctive signatures for functionally related integral cytoplasmic membrane proteins. Mol Microbiol 12, 993-1004.

Sullivan, M. A., Yasbin, R. E. \& Young, F. E. (1984). New shuttle vectors for Bacillus subtilis and Escherichia coli which allow rapid detection of inserted fragments. Gene 29, 21-26.

Tam, R. \& Saier, M. H., Jr (1993). Structural, functional, and evolutionary relationships among extracellular solute-binding receptors of bacteria. Microbiol Rev 57, 320-346.

Tinoco, I., Borer, P. N., Dengler, B., Levine, M. D., Uhlenbeck, O. C., Crothers, D. M. \& Gralla, J. (1973). Improved estimation of secondary structure in ribonucleic acids. Nature New Biol 246, $40-41$.

Weickert, M. J. \& Chambliss, G. H. (1990). Site-directed mutagenesis of a catabolic repression operator sequence in Bacillus subtilis. Proc Natl Acad Sci USA 87, 6238-6242.

Weinstein, L. \& Albersheim, P. (1979). Structure of plant cell walls. IX. Purification and partial purification of a wall-degrading endoarabanase and an arabinosidase from Bacillus subtilis. Plant Physiol 63, 425-432.

Wray, L. V., Jr, Pettengill, F. K. \& Fisher, S. H. (1994). Catabolite repression of the Bacillus subtilis hut operon requires a cis-acting site located downstream of the transcription initiation site. $J$ Bacteriol 176, 1894-1902.

Yang, J., Dhamija, S. S. \& Schweingruber, M. E. (1991). Characterization of a specific $p$-nitrophenylphosphatase gene and protein of Schizosaccharomyces pombe. Eur J Biochem 198, 493-497.

Yanisch-Perron, C., Vieira, J. \& Messing, J. (1985). Improved M13 phage cloning vectors and host strains: nucleotide sequences of the M13mp18 and pUC19 vectors. Gene 33, 103-119.

Received 10 July 1996; revised 7 October 1996; accepted 9 October 1996. 